\title{
Quarterly Earnings, Operating Cash Flow, and Accruals in Future Performance Assessment
}

\section{Rene Coppe Pimentel ${ }^{1}$ Mara Jane Contrera Malacrida ${ }^{1}$}

${ }^{1}$ Universidade de São Paulo, São Paulo, SP, Brazil

Received 18 September 2019. This paper was with the authors for two revisions. Accepted 23 December 2020.

First published online 27 January 2021.

Editor-in-chief: Carlo Gabriel Porto Bellini (D) (Universidade Federal da Paraíba, João Pessoa, PB, Brazil) Associate editor: Robert Iquiapaza (D) (Universidade Federal de Minas Gerais, Belo Horizonte, MG, Brazil)

Reviewers: Rafael Moreira Antônio (D) (Universidade de São Paulo, Ribeirão Preto, SP, Brazil), Paulo Roberto Barbosa Lustosa (Universidade de Brasilia, Brasília, DF, Brazil) and one anonymous reviewer

Editorial assistants: Kler Godoy and Simone Rafael (ANPAD, Maringá, PR, Brazil) 


\section{ABSTRACT}

This paper analyzes the informative content of quarterly earnings, operating cash flows, and accruals to assess future performance. The empirical analysis is based on 270 Brazilian nonfinancial firms listed on B3 from 2005 to 2018. Autoregressive models and variance decomposition were performed. Overall, results show that accounting earnings and accruals have incremental information content over operating cash flows in accessing future financial performance. Firstly, earnings have higher persistence parameters and capture a longer-term perspective showing that earnings, under the accrual regime, are more predictable than cash flows when using their past information. Secondly, the magnitude of accruals positively affects the persistence of earnings. Thirdly, as a component of earnings, operating cash flows are more persistent than the accruals component. Fourthly, high accrual levels are associated with lower future earnings. Finally, earnings have incremental informative power to explain future operating cash flows. This study contributes to the literature by providing evidence of the information content of quarterly performance measures with specific controls for accounting accruals processes, which is useful for financial performance forecasts in markets with low analyst coverage and restricted enforcement mechanisms.

Keywords: earnings persistence; earnings forecast; operating cash flows; quarterly earnings; market efficiency

JEL Code: M41; G150 


\section{INTRODUCTION}

One of the main issues and challenges for investors, analysts, and other market practitioners and participants is to forecast future financial outputs in a world in which firms' future performance and their associated probabilities are not completely known and the markets are neither perfect nor complete (i.e., there is information asymmetry and barriers to fair and efficient markets) (Scott, 2015). These challenges are corroborated by empirical literature, documenting that professional analysts and investors have been failing in providing accurate estimations of future performance (Bradshaw, Drake, Myers, \& Myers, 2012; Hou, Van Dijk, \& Zhang, 2012; Lacina, Lee, \& Xu, 2011; Olsen, 1996).

While Fama and French (2000) suggest that security analysts should exploit and scrutinize the time series process of earnings during the forecast process, Chen (2013) shows that these analysts and investors fail to fully recognize the time series process of earnings and cash flows. In this regard, estimation of future earnings and cash flows are key aspects in financial analysis and firm valuation. Linking accruals included in accounting earnings measurements with future operating cash flow is important for assessing the relevance of accruals and earnings for firm valuation (Farshadfar \& Monem, 2019). However, due to natural uncertainty about the future and the context specificity of financial outputs, the literature has struggled to develop universal forecast models to understand the behavior of financial indicators, especially with regard to earnings, operating cash flows, and accounting accruals (Ball, Gerakos, Linnainmaa, \& Nikolaev, 2016). Hence, no outperforming model or pattern is consensually considered the best in all situations and environments (Dechow, Ge, \& Schrand, 2010).

In this regard, Livnat and Santicchia (2006) claim that careful financial statement users such as financial analysts, investors, and creditors should closely scrutinize a firm's quarterly accruals for the possibility of future reversals. Specifically, accruals are the non-cash component of earnings, representing adjustments made to cash flows to generate a profit measure largely unaffected by the timing of receipts and payments of cash (Ball et al., 2016).

Hence, by reflecting a wide variety of corporate decisions, accruals are assumed to be the key output of the financial reporting system, encompassing everything that drives a wedge between earnings and cash flow, including a firm's sales, production, investment, accounting, and cash management choices (Lewellen \& Resutek, 2019). If investors are fixated only on earnings and ignore information in cash flows from operation and accruals, stock prices may not accurately reflect the economic situation of the firm, leading to market anomalies, such as mispricing and accruals anomaly (Livnat \& Santicchia, 2006).

Different from the existing literature, this paper addresses this issue by analyzing quarterly data of earnings, cash flow from operations - reported in the statement of cash flows -, and accruals, and their assessment of future performance using a sample of 270 Brazilian non-financial firms listed on B3 (São Paulo Stock Exchange) from 2005 to 2018 (10,792 firms - quarterly observations). This sample includes non-financial firms that account for around $98 \%$ of the market capitalization and comprises all available cash flow statement information.

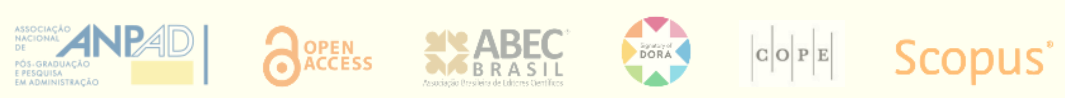


The analysis is conducted by controlling the estimations for accounting accruals methodologies and processes (i.e., controlling the effects of negative performance, extreme values, decreasing performance, volatility of accounting components, and IFRS adoption). The accruals processes have practical importance since they significantly affect future earnings and operating cash flow estimations, by increasing or reducing the accuracy of future performance forecasts by market agents. Overall, extreme accruals, reducing earnings, negative earnings, and more volatile financial performance reduce earnings and cash flows persistence parameters, making forecast even more challenging. In this regard, this paper also provides alternative assumptions for the time series process of earnings, operating cash flows, and accruals.

The relevance of quarterly analysis relies on the fact that market agents tend to revise earnings forecasts after quarterly earnings announcements. Hence, to ignore the fact that comprehensive annual earnings and operating cash flows are anticipated mainly in quarterly reporting might be regarded as incomplete from an efficient market perspective. Considering that $3 / 4$ of annual earnings and operating cash flows are already known when annual measures are reported, careful consideration of quarterly earnings, operating cash flows, and accruals is likely to be extremely important for improving forecasts (Livnat \& Santicchia, 2006).

The informative content of earnings, cash flow, and accruals is not a closed subject, since studies show conflicting evidence and environment specificity for the role played by each measure. Bartov, Goldberg, and Kim (2001), for instance, demonstrate that the superiority of earnings over cash flows is not universal. Rather, it depends on the national reporting regime and attendant institutional factors. In this regard, to the best of our knowledge, no paper combines the analysis of quarterly earnings data, operating cash flow, and the role of quarterly accruals information in the forecast of future values of earnings and operating cash flows in the Brazilian market. Moreover, none of the previous papers controls persistence estimation for the effect of accounting accruals methodology.

Overall, results in this paper show that accounting earnings and accruals contained in earnings have incremental information content on operating cash flows in accessing future financial performance measured by both earnings and cash flow from operations. Firstly, earnings have higher persistence parameters and capture a longer-term perspective of time series components than cash flows from operations, showing that earnings, under the accrual accounting regime, are more predictable than operating cash flows when using their past information. Secondly, the magnitude of accruals is associated positively with the persistence of earnings. Thirdly, as a component of earnings, operating cash flows are more persistent than the accruals component. Fourthly, high accruals levels are associated with lower future earnings. Finally, earnings have incremental informative power to explain future operating cash flows. The study contributes to the literature by providing evidence of the information content of quarterly performance measures (earnings, operating cash flows, and accruals) with regard to future performance and an incremental tool for forecasting future performance of firms by analyzing the Brazilian market. This is an emerging capital market with a low level of investor protection, low analyst coverage, and restricted enforcement mechanisms. Due to the recent legal requirement for reporting the

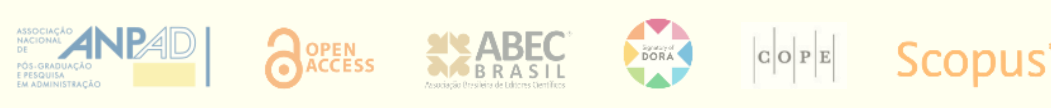


statement of cash flows (from 2005), the time series length can now provide valuable and robust analysis comparable to other developed economies.

In line with Call, Hewitt, Shevlin, and Yohn (2016), this study also provides an incremental tool for forecasting future performance of firms (in terms of earnings and operating cash flows) by improved understanding of the time series dynamics of quarterly earnings and cash flows. This aspect has practical relevance since analysts' forecasts have been providing disappointing accuracy and estimation biases (Olsen, 1996), have been less accurate than a naive and simple time series process (Bradshaw et al., 2012; Gatsios, Lima, \& Magnani, 2018; Lacina, Lee, \& Xu, 2011; Hou et al., 2012), and have been failing in fully recognize the time series process of earnings and cash flows (Chen, 2013). In this regard, more persistent earnings and operating cash flows are better inputs to valuation models (Call, Hewitt, Shevlin, \& Yohn, 2016) and the high or low persistence and predictability are related to the pattern of earnings, operating cash flows, and, in particular, accruals: financial performance with different accruals processes and anomalies have different predictability power.

The remainder of this paper is organized as follows. Section 2 reviews the relevant literature, presents specificities of the Brazilian market, and formulates the hypotheses. Section 3 presents the empirical models and variables. Section 4 presents the sample and description of the variables. Section 5 introduces the empirical findings and discusses the results. Section 6 provides additional tests and assumptions for the empirical study. Finally, the last section offers concluding remarks and suggestions for future research.

\section{LITERATURE OF INTEREST AND HYPOTHESIS DEVELOPMENT}

\section{Persistence of performance measures: earnings vs. operating cash flows}

The financial performance of a firm - measured on earnings (accruals) and operating cash flows basis - has permanent and transitory components (Easton \& Zmijewski, 1989). The permanent portion of performance indicates that new information in current performance will affect expected future outputs while the transitory portion will not help explain expected future performance as its effects will not persist over time. Hence, persistence is related to the continuation of an effect if a series receives an external shock: shocks tend to persist for a long time in high persistent series, while they tend to return to their historical average trajectory in low persistent series (Baginski, Lorek, Willinger, \& Branson, 1999; Baginski, Branson, Lorek, \& Willinger, 2003). Knowing the level of persistence in the series (and comparing them, as done in this paper) provides important information to potential decision-making, especially if the two series - earnings and operating cash - compete as useful performance measures to enable future estimation and asset valuation (Francis, Glandon, \& Olsen, 2013, Dechow \& Ge, 2006). Financial theory says (and shows) that more persistent financial performances tend to be better inputs for business valuation models (Dechow et al., 2010).

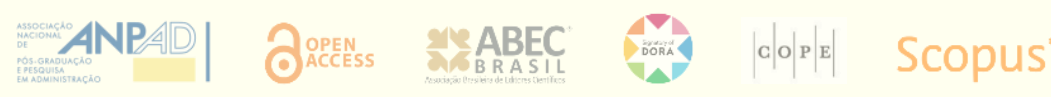


Hence, the persistence of earnings and operating cash flows have been acknowledged as a valuable element for firms' valuation perspectives (Ohlson, 1995; Call et al., 2016), since firms with more persistent earnings and/or cash flows have a more sustainable stream that will make it a more useful input into equity valuations models (Dechow et al., 2010). In this regard, Call et al. (2016) document that the usefulness of persistence parameter for valuation purposes is valid for both metrics, earnings and operating cash flows; moreover, the authors show that the differential persistence of accruals and operating cash flows is incrementally useful for forecasting.

Under the accruals regime (accounting earnings performance measure), the variations in cash inflow and outflows - can be allocated or deferred along the economic life of assets and obligations; as a consequence, accruals are expected to smooth the volatility elements of cash in financial states, thus making earnings more persistent compared to cash. In the long run, as this paper acknowledges, the two series tend to be equalized; however, the comparison between them, in short and medium periods, may provide useful evidence that accounting information, based on the accruals regime, increases the predictive ability, as claimed by the current conceptual framework of IFRS, as part of the relevance of accounting information.

In this regard, Larson, Sloan, and Zha Giedt (2018) provide three main roles for accounting accruals: First, to capture investments related to growth in the scale of business operations. Second, to alleviate timing differences between economic events and their associated cash flows effects. Third, to reflect the asymmetric timely recognition of losses. Additionally, Dechow and Ge (2006) claim that the revenue recognition rules and the matching principle improve earnings as a measure of performance relative to cash flows. Thus, by assuming that the accruals regime provides better assessment of future financial performance output, it is possible to expect earnings to be more persistent than operating cash flow, which leads to the first hypothesis of this paper:

H1: Quarterly earnings are more persistent than quarterly operating cash flows.

The literature in finance and accounting has strongly analyzed the determinants of earnings persistence, such as earnings components (cash and accruals), fundamental performance, growth, volatility, and risk (Dechow et al., 2010; Hui, Nelson, \& Yeung, 2016). Although most of the literature is focused on earnings persistence, Francis, Glandon, and Olsen (2013) compare the persistence (predictive ability) of different measurements and compositions of operating cash flows and find that the way operating cash flow is defined affects its persistence, showing that the discretionary (or regulatory) components of operating cash flow can affect future cash flow estimates.

In this regard, Dechow and Ge (2006) show that persistence of earnings and cash flow are determined by the level (magnitude) of accruals, since accruals improve the persistence of earnings relative to cash flows in high accrual firms, but reduce earnings persistence in low accrual firms. According to this empirical finding, the magnitude of accruals is expected to affect the persistence of earnings and operating cash flows, which leads to the second hypothesis of this paper:

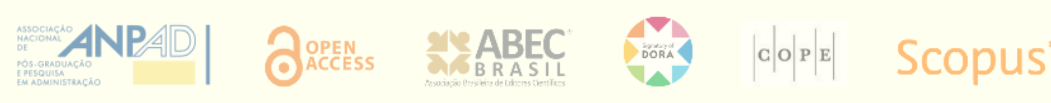


H2: The magnitude of accruals significantly affects the persistence of earnings and operating cash flows.

The concurrent proxies for firm performance, based on earnings and operating cash flows, have also been analyzed in terms of market expectations. Livnat and Santicchia (2006) documented that operating cash flow has superior information content than accruals in the short term (up to three fiscal quarters) for market prices, while accruals are more associated with market prices after four quarters. Similarly, Dechow and Ge (2006) document that special items in earnings are associated to higher future stock returns, especially for high accrual firms.

\section{Accruals and operating cash flows as components of earnings and future earnings assessment}

A second field of empirical research analyzes the role of operating cash flows and accruals as components of core earnings. "Accruals are a key output of the financial reporting system, encompassing everything that drives a wedge between earnings and cash flow" (Lewellen \& Resutek, 2019). In this view, accruals and operating cash flows are features that affect future earnings and each component has different persistence and affects future earnings estimation.

The seminal study of Sloan (1996) documented that operating cash flow is more closely associated with future earnings than accruals since accruals reverse faster than earnings in subsequent periods. In other words, the accrual components of earnings are less persistent than operating cash flows. Hence, market agents that focus on accounting earnings rather than operating cash flows tend to overestimate the persistence of accruals and underestimate the persistence of net operating cash flows.

Hui, Nelson, and Yeung (2016), among others, also document that cash flow is the most persistent component of earnings while firm-specific accruals are the least persistent. Similarly, Livnat and Santicchia (2006) document that the accounting system that includes accruals in current earnings is less persistent into future earnings, regardless of whether accruals are managed to produce a desired level of current income or are just due to genuine but erroneous managerial expectations about the future.

According to Lewellen and Resutek (2019), there are three possible explanations to low persistence of accruals. First, subjectivity and distortions in financial statements lead to transitory measurement error in accruals and earnings. The second explanation suggests that accruals are closely linked to investment activities leading to decreasing returns to scale and/or increasing costs associated with investment. The third explanation is based on the way firms' profits and working capital respond to demand and supply shocks in product markets.

As a practical consequence of the higher persistence of cash compared to accruals, the economic fundamentals that drive firms' performance and accounting metrics are jointly informative about firms' future earnings. This leads to the third hypothesis of this paper:

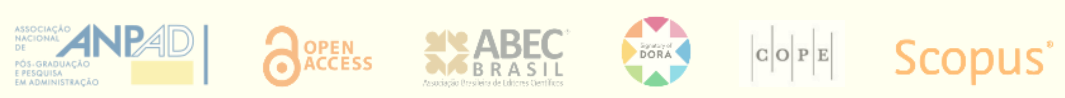


H3: As a component of earnings, operating cash flows are more persistent than the accruals component.

The empirical literature has also documented that firms reporting higher accruals tend to present lower subsequent earnings (Dechow et al., 2010; Larson et al., 2018). According to Lewellen and Resutek (2019), high accruals predict high subsequent sales growth but a "long-lasting drop in both profits and profitability” (Lewellen \& Resutek, 2019, p. 336). Additionally, accruals are associated with an increase in future market competition and this evidence suggests that accruals are correlated with abnormally high profitability attracting new entrants to the industry.

Provided that higher accruals tend to present lower subsequent earnings, the fourth hypothesis of the paper is that:

H4: High accruals levels are associated with lower future (subsequent) earnings.

\section{Accruals and future operating cash flows predictions}

A third field in the literature and empirical research seeks to analyze the role of accruals informativeness to explain future operating cash flows and, consequently, firm value by means of market prices and market returns. In this regard, Nichols and Wahlen (2004) theoretically explore how current period earnings (and accruals) provide information to predict future earnings, to develop expectations about future dividends, and to determine share value.

Recent evidence in Farshadfar and Monem (2019) documents that accruals are important for explaining future operating cash flows and that accrual components in earnings play different roles in explaining future operating cash flow. Similarly, Barth, Clinch, and Israeli (2016) characterize the information about future cash flows reflected in accruals and show that investors can, from accruals, gather information about the next period's economic factors and the transitory part of one component of the next period's cash flow. Additionally, Barth et al. (2016) show how that information is used in valuation and cash flow and earnings forecasting.

Barth, Cram, and Nelson (2001) analyze the role of accruals in predicting future operating cash flows and show that accruals accounting data significantly enhance the predictive ability for future cash flow. The operating cash flow and accrual components of current earnings have high predictive ability for future cash flows. In a cross-country analysis, Bartov et al. (2001) show that the relevance of earnings and cash flows to valuation purposes is context-specific, since AngloSaxon countries have accounting earnings as the greater explanatory variable for stock returns when compared to cash flow metrics. Conversely, non-Anglo-Saxon countries use cash flows as the 'king' for equity valuation.

Considering the expectation that current period earnings (and accruals) provide information to predict future operating cash flows, the fifth hypothesis of this study claims that:

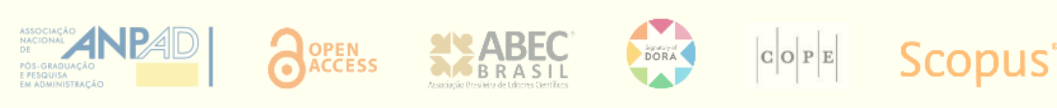


H5: Earnings (and accruals components) have incremental information to explain future operating cash flows.

In terms of market recognition of future outcomes, Ball, Gerakos, Linnainmaa, and Nikolaev (2016) show that expected market returns increase in profitability and decrease in accruals by showing that cash-based operating profitability (a measure that excludes accruals) outperforms measures of profitability that include accruals.

\section{The relevance of quarterly data analysis and emerging market literature}

A common characteristic of the literature mentioned in the previous sections is that it concentrates mainly on annual earnings information and developed markets and much less is known about quarterly earnings/cash flows patterns in emerging economies.

Regarding quarterly financial data, Kothari (2001) provides reasons supporting empirical analysis of quarterly data. Firstly, quarterly data are seasonal in many industries because of the seasonal nature of their main business activity. Secondly, quarterly accounting data are timelier, so the use of quarterly earnings or cash forecast as a proxy for the market's expectation is likely to be more accurate than using annual financial assessments. Thirdly, GAAP requires that the quarterly reporting period be viewed as an integral part of the annual reporting period. Finally, less stringent data availability requirements are necessary using quarterly rather than annual earnings to achieve the same degree of precision of the forecasts.

While a number of studies analyze the time series properties of quarterly earnings (Baginski et al., 2003; Brown \& Rozeff, 1979; Chen, 2013; Easton \& Zmijewski, 1989; Foster, 1977; Kormendi \& Lipe, 1987; Pimentel \& Aguiar, 2012), only a few studies compare the informative ability of earnings, operating cash flows, and the role of quarterly accruals. Amongst them, Lorek and Willinger (1996) analyze the time series properties and predictive ability of cash flow data using quarter-by-quarter (seasonal) and quarter-on-quarter (adjacent) reports of earnings and operating cash flow information and show that cash flow prediction is enhanced by consideration of earnings and accrual accounting data. Livnat and Espinosa (2008), using quarterly and rolling four-quarter data, show that quarterly net operating cash flow is a stronger signal of the next quarter's market equity returns than accruals are.

As far as emerging economies are concerned, a much smaller amount of research is available. In relation to earnings persistence, Coelho, Aguiar, and Lopes (2011) show that different industries affect abnormal earnings persistence differently and that abnormal earnings persistence has no informational content. Kolozsvari and Macedo (2016) analyze the influence of income smoothing on annual earnings persistence and show that increased transience in the time series decreased earnings persistence resulting in a loss in earnings informativeness to market agents. Pimentel and Aguiar (2016) analyze the implications of earnings persistence for financial analysis and compensation contracts and document that more persistent earnings are a better input to valuation models and are likely to serve as a proxy for long-term market and managerial orientation.
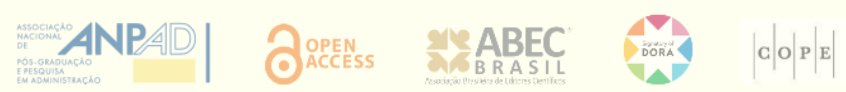
In relation to earnings and cash flow predictions, Malacrida, Lima, Fávero, and Lima (2010) compare the capacity of earnings, operating cash flows, and accruals to predict future operating cash flows and show that earnings decomposed into various accrual components have greater capacity to predict future operating cash flows. Additionally, Leal, Girao, Lucena, and Martins (2017) analyze the impact of extreme earnings and cash flows on the persistence, value relevance, and accruals quality of Brazilian listed firms and document that the presence of extreme components of annual earnings and cash flows values negatively influence market information quality and future performance prediction.

Contrary to the bulk of international evidence, Takamatsu and Fávero (2013) and Cupertino, Martinez, and Costa (2012) document that the market agents correctly price the accrual component of earnings and that there is no accrual anomaly in the Brazilian market. Other studies analyze the relevance of annual earnings and cash flow to market agents. For instance, Pimentel and Lima (2015) and Pimentel (2015) show that the way market agents recognize earnings persistence depends on the time series assumption adopted in the research design and this relationship is also affected by extreme (non-linear) effect of earnings and risk.

To the best of our knowledge, no paper combines the analysis of seasonal quarterly earnings data, operating cash flow, and the role of quarterly accruals information in the prediction of future values of earnings and operating cash flows. Moreover, none of the previous papers controlled for the effects of accounting accruals methodology effects, namely: the differential impact of negative values, the decreasing effect in earnings and cash flows, and extreme values of earnings, cash, and accruals.

The relevance of the current analysis relies on the fact that, due to the previously mentioned characteristics of the emerging markets (low analyst coverage, higher uncertainty, lower levels of enforcement and investor protection, etc.), the deep understanding of the time series process of earnings, operating cash flows, and accruals is a key aspect in future financial performance forecast and has high practical implications: in markets claimed to be more developed, Olsen (1996) shows that "experts' earnings predictions exhibit positive bias and disappointing accuracy" (Olsen, 1996, p. 37), due to incomplete knowledge, incompetence, and/or misrepresentation, and they are moved by the human desire for consensus. Additionally, the literature shows that when performed well, "simple random walk forecasts are more accurate than analysts' forecasts over longer horizons" (Bradshaw et al., 2012, p. 944); "naïve model forecasts contain a large amount of incremental information over analysts' forecast” (Lacina, Lee, \& Xu, 2011, p. 77); and mechanical estimates are more reliable than analysts' forecast because "earnings forecast generated by the cross-sectional model are superior to analysts' forecasts in terms of coverage, forecast bias, and earnings response coefficient" (Hou et al., 2012, p. 504). Chen (2013) justifies these empirical findings by the fact that analysts and investors fail in fully recognize the time series process of earnings and cash flows.

Similarly, Gatsios, Lima, and Magnani (2018) evaluated the analysts' forecasts and the random walk models, both simple and with growth, in the short and long term, for Brazilian publicly

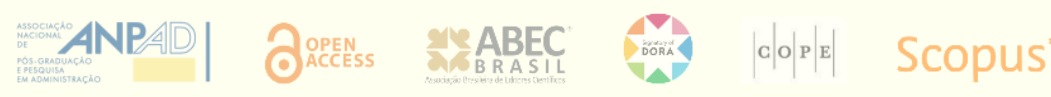


traded companies during the period from 2010 to 2015, and the evidence suggests forecasting superiority of the random walk models when compared to the market analysts' forecasts.

\section{RESEARCH DESIGN AND VARIABLES DEFINITIONS}

\section{Earnings and operating cash flow persistence}

This paper follows the literature to measure and define operating accruals by using data directly from the statement of cash flows, which mitigates the error in accrual estimation (Dechow et al., 2010; Dechow \& Ge, 2006; Hribar \& Collins, 2002; Larson et al., 2018). Thus, accruals (accr) are the difference between quarterly earnings (earn) and quarterly cash flows from operations (cfo) reported on statement of cash flows:

$$
a c c r=e a r n-c f o
$$

Similar to Francis et al. (2013) and Dechow and Ge (2006), this paper also extends the well documented time series assumptions in earnings persistence literature to operating cash flows and accruals. Specifically, the persistence level is a dynamic property of any time series that gives us a general understanding of the series in question. Thus, persistence is related to the continuation of an effect if a series receives an external shock: shocks tend to persist for a long time in high persistent series, while shocks tend to return to their historical average trajectory in low persistent series. Knowing the level of persistence in the series (and comparing them, as done by this paper) provides important information to potential decision-making, especially if the two series - earnings and operating cash - compete as useful performance measures to enable future estimation and asset valuation.

The basic model for earnings and cash flow persistence estimation is based on the well-accepted first-order autocorrelation model of quarterly time series of seasonally differenced earnings (SDE) approach (Baginski et al., 2003; Brown \& Rozeff, 1979; Chen, 2013; Easton \& Zmijewski, 1989; Foster, 1977; Kormendi \& Lipe, 1987; Lorek \& Willinger, 1996). Thus, the persistence parameter analysis is described as follows:

$$
\begin{aligned}
\left(e a r n_{i t}-e a r n_{i t-4}\right) & =\alpha_{0}+\alpha_{1}\left(e a r n_{i t-1}-e a r n_{i t-5}\right)+\varepsilon_{t i} \\
\left(c f o_{i t}-c f o_{i t-4}\right) & =\alpha_{0}^{*}+\alpha_{1}^{*}\left(c f o_{i t-1}-c f o_{i t-5}\right)+\varepsilon_{t i}
\end{aligned}
$$

where seasonally differenced earnings and operating cash flows were scaled by total assets at the beginning of the period and the subscripts $i$ and $t$ indicate firm $i$ in a specific quarter $t$. The intercepts, $\alpha_{0}$ and $\alpha_{0}^{*}$, and the persistence parameters measures, $\alpha_{1}$ and $\alpha_{1}^{*}$, are the slopes of sample-aggregate coefficients in Equations $1 \mathrm{a}$ and $1 \mathrm{~b}$. For the sake of brevity in notation, the differenced earnings $\left(e a r n_{i t}-e a r n_{i t-4}\right)$ and operating cash flows $\left(c f o_{i t}-c f o_{i t-4}\right)$ scaled by assets are here denoted as SDE and SDC, respectively. At the end of the paper, an additional 
test with an alternative time series assumption is also provided, specifically the non-integrated first-order autocorrelation in adjacent and seasonal quarterly parameters.

In order to account for the earning and operating cash flow streams and accounting methodology, an extended model was used by including the following control variables. Firstly, extreme earnings (dbigearn) or operating cash flow (dbigcfo) changes assuming 1 when the change in quarteron-quarter earnings (and operating cash flow) falls into the top or into the bottom 10 percent of the distribution in $t-1$ and 0 otherwise. Secondly, a decreasing dummy, decrearn and decrcfo, assuming 1 when earnings and operating cash flow decrease in relation to $t-1$, respectively, and 0 otherwise. Thirdly, a negative earnings (loss) dummy, dnegearn and dnegcfo, for negative earnings and negative operating cash flow, respectively, assuming 1 when earnings in $t-1$ is negative and 0 otherwise. Fourthly, earnings and operating cash flow volatilities by considering VEARank and VCFRank the rank positions of earnings and operating cash flow volatility, respectively, associated with a sample observation in quarter $t$; $\mathrm{N}$ denotes the number of observations in that quarter; volearn and volcfo are given by volearn $=\left(\right.$ VEARank $\left._{i t}-1\right) /(\mathrm{N}-1)$ and volcfo $=\left(\right.$ VCFRank $\left._{i t}-1\right) /(\mathrm{N}-$ 1), respectively. Finally, considering that earnings persistence is potentially affected by the accounting model, this paper includes a control for IFRS adoption by including a dummy variable assuming 1 for periods after full IFRS adoption from the first quarter of 2010 to the most recent observation and 0 for period prior IFRS adoption (before the first quarter of 2010). The extended model is described as:

$$
\begin{aligned}
& S D E_{i t}=\alpha_{0}+\alpha_{1} S D E_{i t-1}+\alpha_{2} S D E_{i t-1} * \text { dbigearn }_{i t-1}+\alpha_{3} S D E_{i t-1} * \\
& \text { decrearn }_{i t-1}+\alpha_{4} S D E * \text { dnegearn }_{i t-1}+\alpha_{5} S D E_{i t-1} * \text { volearn }_{i t-1}+ \\
& \alpha_{6} S D E_{i t} * \text { ifrs }_{t}+\varepsilon_{t i} \\
& S D C_{i t}=\alpha_{0}^{*}+\alpha_{1}^{*} S D C_{i t-1}+\alpha_{2}^{*} S D C_{i t-1} * d b i g c f o_{i t-1}+\alpha_{3}^{*} S D C_{i t-1} * \\
& \operatorname{decrcfo}_{i t-1}+\alpha_{4}^{*} S D C_{i t-1} * \text { dnegcfo } o_{i t-1}+\alpha_{5}^{*} S D C_{i t-1} * \text { volecfo }_{i t-1}+ \\
& \alpha_{6}^{*} S D C_{i t} * i f r s_{t}+\varepsilon_{t i}
\end{aligned}
$$

Coefficients $\alpha_{2}, \alpha_{3}, \alpha_{4}$, and $\alpha_{5}$ are expected to vary negatively to persistence (i.e., negative coefficients are expected), suggesting that the large changes in earnings/cash flow, decrease in earnings/cash flow, and negative earnings/cash flows are assumed to reduce the persistence parameter. In this regard, Table 1 summarizes the economic interpretation of each control variable. Overall, accruals process related to (1) extreme, (2) reducing, (3) negative, and (4) volatile financial performance reduces earnings and cash flows persistence parameters, making forecast more challenging.

In order to test the second hypothesis of this paper, additional estimations are performed using Equations $2 \mathrm{a}$ and $2 \mathrm{~b}$ according to the magnitude of operating accruals by splitting the sample in the top 25\% higher and the 25\% lower accruals (top and bottom quartiles). The portfolio approach is widely performed in the finance and accounting literature (see, for instance: Dechow $\&$ Ge, 2006; Larson et al., 2018), usually by splitting the sample into deciles. However, due to the low number of available observations in the Brazilian market, the sample was split into quartiles, each quartile providing observation of more than 2,200 firm-quarterly observations, a number in line with international literature in the field.

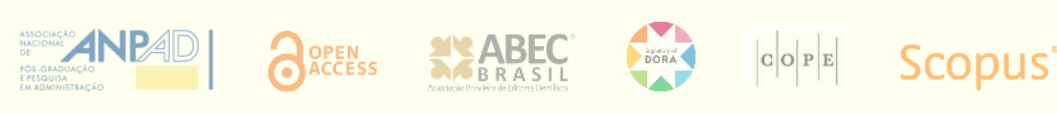


Following previous literature, the autoregressive parameters are estimated under the OLS framework and assume linearity of estimated coefficients under time series assumptions with correction for heteroscedasticity.

Table 1

Economic interpretation of control variables

\begin{tabular}{|c|c|c|c|c|}
\hline Variable & Symbol & $\begin{array}{l}\text { Expected } \\
\text { signal }\end{array}$ & Author & Economic interpretation \\
\hline $\begin{array}{l}\text { Extreme } \\
\text { earnings and } \\
\text { operating cash } \\
\text { flows }\end{array}$ & dbigcfo & - & $\begin{array}{l}\text { Easton and } \\
\text { Zmijewski (1989); } \\
\text { Leal et al. (2017) }\end{array}$ & $\begin{array}{l}\text { Extreme values of earnings and operating cash flows are } \\
\text { typically transitory and non-recurrent elements in their nature. } \\
\text { These elements are not assumed to persist throughout the } \\
\text { period (for instance, a big loss or gain due to an unexpected } \\
\text { event or specific condition). Thus, the presence of extreme } \\
\text { values should be negative related to the persistence of financial } \\
\text { performance. }\end{array}$ \\
\hline $\begin{array}{l}\text { Decrease } \\
\text { earnings and } \\
\text { operating cash } \\
\text { flows }\end{array}$ & $\begin{array}{l}\text { decrearn } \\
\text { decrcfo }\end{array}$ & - & Chen (2013) & $\begin{array}{l}\text { Managers should pursue wealth maximization of stakeholders. } \\
\text { Consequently, firms should run their activities expecting } \\
\text { maximization of their economic outputs. Decrease in earnings or } \\
\text { operating cash flows in a given period should make managers } \\
\text { take actions to revert it to increasing figures in the shortest } \\
\text { period possible. Thus, the presence of decrease earnings of } \\
\text { operating cash flows should be negatively related to the } \\
\text { persistence of financial performance. }\end{array}$ \\
\hline $\begin{array}{l}\text { Negative } \\
\text { earnings and } \\
\text { operating cash } \\
\text { flows }\end{array}$ & dnegearn & - & Chen (2013) & $\begin{array}{l}\text { Similar to decrease in earnings, losses are not associated with } \\
\text { the wealth maximization view, especially in persistent losses. } \\
\text { Hence, the presence of loss or negative operating cash flows in } \\
\text { a given period should make managers take actions to revert it to } \\
\text { positive figures in the shortest period possible. Thus, the } \\
\text { presence of negative earnings should be negatively related to } \\
\text { the persistence of financial performance. } \\
\text { Note that a period of decreasing in earnings does not } \\
\text { necessarily mean negative earnings and a period of negative } \\
\text { earnings does not mean a period of decreasing in earnings. One } \\
\text { is related to earnings 'movement,' the other with earnings } \\
\text { 'realization.' }\end{array}$ \\
\hline $\begin{array}{l}\text { Volatility of } \\
\text { earnings and } \\
\text { operating cash } \\
\text { flows }\end{array}$ & volcfo & - & $\begin{array}{l}\text { Clubb and Wu } \\
\text { (2014); Frankel } \\
\text { and Litov (2009) }\end{array}$ & $\begin{array}{l}\text { More volatile earnings or operating cash flows mean that the } \\
\text { presence of transitory components is common in the time series } \\
\text { process. The firms operating in more stable activities (such as } \\
\text { utilities) are less exposed to variation due to other variables such } \\
\text { as commodities or other macroeconomic conditions. Thus, more } \\
\text { volatile earnings should be negatively related to the persistence } \\
\text { of financial performance. }\end{array}$ \\
\hline IFRS & IFRS & $+/-$ & $\begin{array}{l}\text { Barth, Landsman, } \\
\text { and Lang (2008); } \\
\text { Byard, Li, and Yu } \\
\text { (2011) }\end{array}$ & $\begin{array}{l}\text { The literature offers two expectations to this variable. On the one } \\
\text { hand, the IFRS adoption might have increased the quality of } \\
\text { accounting information and relevance, and, thus, a positive } \\
\text { effect is expected, once we assume that more persistence is } \\
\text { related to better accounting information (Dechow et al., 2010). } \\
\text { On the other hand, authors argue that the IFRS can incorporate } \\
\text { more volatility in the financial statements due to inclusion of fair } \\
\text { value measures in the asset-liability view (Kusano, 2012). }\end{array}$ \\
\hline
\end{tabular}




\section{Accruals and operating cash flows as components of earnings}

Following Lewellen and Resutek (2019), the next step of this paper is to analyze the role of accruals and operating cash flows as determinants of earnings persistence by adapting their annual model to the first-order seasonally differenced quarterly earnings model as:

$$
S D E_{i t+1}=\gamma_{0}+\gamma_{1} S D C_{i t}+\gamma_{2} S D A_{i t}+\varepsilon_{t i}
$$

where SDE, SDC, and SDA are quarterly time series of seasonally differenced earnings, operating cash flows, and accruals, respectively. Differenced earnings, operating cash flows, and accruals are deflated by assets at the beginning of the period. As described before, subscripts $i$ and $t$ refer to firms and quarters in the sample. Accruals are the total operating accruals calculated as the difference between earnings and operating cash flows from the statement of cash flows $($ accr $=$ earn $-c f o$ ). In this context, persistence refers to the slopes in Equation 3 and the low persistence of accruals refers to the empirical observation that $\gamma_{2}<\gamma_{1}$. That is, accruals and cash flows are positively related to future earnings but the predictive slope on accruals is lower (Lewellen \& Resutek, 2019).

Alternatively, complementary regression can be estimated by using seasoned differenced earnings rather than operating cash flow:

$$
S D E_{i t+1}=\gamma_{0}^{*}+\gamma_{1}^{*} S D E_{i t}+\gamma_{2}^{*} S D A_{i t}+\varepsilon_{t i}
$$

According to Lewellen and Resutek (2019), the difference between Equations 3 and 4 is that the slope on accruals in Equation 4 equals the differential persistence of accruals and cash flow. Consequently, the low persistence of accruals implies that $\gamma_{2}^{*}<0$, i.e., accruals are negatively related to future earnings controlling for current earnings (Lewellen \& Resutek, 2019). Note that earnings are composed by operating cash flows and accruals, but the correlation between earnings and operating cash is higher than the correlation between earnings and accruals. This is motivated because most of the variation in earnings is driven by cash dynamics. According to Larson, Sloan, and Zha Giedt (2018), this evidence is consistent with the economic roles of accruals in capturing investments related to growth in the scale of business operation, in alleviating timing differences between economic events and their associated cash flows, and in reflecting the asymmetric timely recognition of losses.

\section{Accruals and future operating cash flows predictions}

Consistent with recent evidence in Farshadfar and Monem (2019) and Barth et al. (2016), this paper tests whether the ability of total operating accruals, and thus of earnings, improves the explanation of future cash flow from operations as reported in the statement of cash flows. Since previous results in this paper suggested low persistence of seasonal differences operating cash flows, the quarterly data model suggested by Lorek and Willinger (2009) was used; by assuming that operating cash flow can also be described as exhibiting quarter-to-quarter (adjacent) and/or quarter-by-quarter (seasonal) relationships, the following regression is estimated:

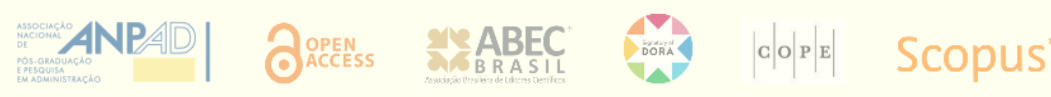




$$
c f o_{i t+\tau}=\delta_{0}+\delta_{1} c f o_{i t}+\delta_{2} c f o_{i t-3}+\delta_{3} a c c r_{i t}+\delta_{4} a c c r_{i t-3}+\varepsilon_{t i}
$$

where $c f o$ and $a c c r$ are quarterly operating cash flows and accruals deflated by assets, respectively. Subscripts $i$ and $t$ refer to firms and quarters in the sample and $\tau$ is the number of quarters ahead varying from one to four quarters. Significant coefficients of accruals $\left(\delta_{3}\right.$ and $\left.\delta_{4}\right)$ suggest that accruals have incremental information content over operating cash flows alone (Farshadfar $\&$ Monem, 2019).

Additional analyses are also conducted in order to decompose diagonal regression-based inequality variance under the Fields' (2003) approach with explanation for future earnings and cash flow, one and four quarters ahead. The base empirical model for variance decomposition is described as:

$$
c f o_{i t+1}=\alpha_{0}+\alpha_{1} e a r n_{i t}+\alpha_{2} c f o_{i t}+\varepsilon_{t i}
$$

The one $(t+1)$ and four quarters ahead dependent variable was also used $(t+4)$, in the seasonal approach. Equation 6 was estimated for the entire sample and broken into samples with the 25\% higher and the $25 \%$ lower accruals separately.

\section{SAMPLE AND VARIABLE DESCRIPTIVE}

Sample selection began with all 364 Brazilian companies listed on B3 (São Paulo Stock Exchange) from 2005 to 2018 with data available at the Economatica database. In the initial sample, 34 banks, 43 firms not publicly traded in the stock exchange (i.e., firms without stock liquidity - at least one share trading activity each year of analysis; these firms are mostly represented by companies with shares negotiated in an over-the-counter market or are in liquidation) and 16 firms, which did not have a minimum of twelve continuous series of quarterly earnings and operating cash flow, were excluded from the analysis. The lack of information is due to firms with recent IPOs or that traded for only a short period and were acquired or liquidated. This yielded a total of 270 non-financial firms. The total period (from the first quarter of 2005 to the third quarter of 2018) is defined by the availability of quarterly information of operating cash flow on the cash flow statement. This set provides 10,792 firm-quarter observations of earnings (earn), operating cash flow (cfo), and total accruals (accr) and 8,466 continuous firm-year observations after seasonally differencing, with different time series lengths among the firms.

Panel A of Table 2 shows the descriptive statistic of the three main variables and Panel B shows the Pearson (lower diagonal) and Spearman rank-order (upper diagonal) coefficients among them. Overall, quarterly cash flows from operations are, on average, higher than earnings evidencing an average negative impact of accruals (i.e., operating cash flows are, on average, reduced by accruals in order to conciliate with earnings); moreover, quarterly operating cash flows are slightly more volatile than earnings (high standard deviation). 
Naturally, correlation analysis in Panel B of Table 2 shows that earnings are positively and significantly related to their determinants (operating cash flow and accruals), while operating cash flow moves inversely with accruals: when cash flows are large, accruals tend to be small and viceversa.

Table 2

Descriptive statistics and correlations

\begin{tabular}{|c|c|c|c|c|c|c|c|c|}
\hline \multicolumn{9}{|c|}{ Panel A - Description of the variables } \\
\hline$\underline{\text { Variable }}$ & Obs. & Mean & Std. dev. & Min. & $\underline{5 \%}$ & $\underline{50 \%}$ & $\underline{95 \%}$ & Max. \\
\hline Earnings (earn) & 10,792 & -0.006 & 0.233 & -7.200 & -0.070 & 0.007 & 0.047 & 12.421 \\
\hline Oper. cash flow (cfo) & 10,792 & 0.007 & 0.252 & -12.048 & -0.053 & 0.015 & 0.072 & 12.476 \\
\hline Accruals (accr) & 10,792 & -0.014 & 0.220 & -6.818 & -0.096 & -0.009 & 0.061 & 11.608 \\
\hline \multicolumn{9}{|c|}{ Panel B - Pearson and Spearman correlations } \\
\hline & \multicolumn{3}{|c|}{ Earnings (earn) } & \multicolumn{2}{|c|}{ Oper. cash flow (cfo) } & & \multicolumn{2}{|c|}{ Accruals (accr) } \\
\hline Earnings (earn) & & & & & $48^{* * *}$ & & 0.37 & \\
\hline Oper. cash flow (cfo) & \multicolumn{3}{|c|}{$0.592^{* * *}$} & & & & \multicolumn{2}{|c|}{$-0.625^{* * *}$} \\
\hline Accruals (accr) & \multicolumn{3}{|c|}{$0.382^{* * *}$} & \multicolumn{2}{|c|}{$-0.518^{* * *}$} & & & \\
\hline
\end{tabular}

Accruals (accr)

Panel C - Distributional characteristics of firm-specific persistence parameter $\left(\alpha_{1}\right)$

\begin{tabular}{|c|c|c|c|}
\hline & Earnings (earn) & Oper. cash flow (cfo) & Accruals (accr) \\
\hline Mean & 0,175 & 0,025 & 0,031 \\
\hline Std. deviation & 0,241 & 0,258 & 0,238 \\
\hline 5th percentile & $-0,191$ & $-0,425$ & $-0,363$ \\
\hline 25th percentile & 0,022 & $-0,137$ & $-0,116$ \\
\hline 50th percentile & 0,136 & 0,028 & 0,036 \\
\hline 75th percentile & 0,349 & 0,182 & 0,172 \\
\hline 95th percentile & 0,585 & 0,438 & 0,437 \\
\hline
\end{tabular}

Finally, in a descriptive way, Panel C of Table 2 shows the firm-specific estimates of Equations 1a and $1 \mathrm{~b}$. Although the main analysis of this paper is based on systematic parameters of persistence, results displayed in Table 2 suggest strong acceptance of the first hypothesis, i.e., quarterly earnings are more persistent than operating cash flows. On average and in all percentiles, earnings persistence is higher than cash flow persistence. From the 270 firms in the sample, 183 (68\% of the firms) presented earnings persistence higher than cash persistence. Regarding operating accruals persistence, since it is the difference of performance measures, it follows similar patterns than cash flows with slightly larger coefficients (not statistically significantly different, however).

It is also important to note that a large number of cash flow persistence coefficients are negative (123 firms) while a much smaller number of firms presented negative earnings persistence coefficients (59 firms). 


\section{EMPIRICAL ANALYSES AND FINDINGS}

The empirical study is divided in three parts. First, the comparison of earnings and operating cash flow persistence parameters and the effect of magnitude of accruals. Second, the analysis of relevance of operating cash flows and accruals as components of earnings and effect of magnitude of accruals in assessing the relevance of cash and accruals in earnings. Third, the power of current earnings and cash flows to explain the variance of future values on earnings and cash flows from operations.

\section{Estimation of quarterly earnings, operating cash flows, and accruals persistence}

Table 3 shows the estimation outputs of the basic (Equations 1a and 1b) and the extended model (Equations 2a and 2b) for earnings and operating cash flows. First, results clearly show that earnings have much higher and significant persistence parameters than cash flows from operations. The results hold true for the base and the extended models. In relation to operating cash flow persistence, it is notable that the persistence estimates are not statistically significant in any of the models (base and extended), suggesting a very low relationship (and low forecasting ability) between current and future outcomes of operating cash flows.

When comparing the two estimation approaches - the base and extended models - it is possible to see that, by controlling persistence estimation, the extended model provides a higher magnitude of persistence parameter, suggesting that the controlling variables provide useful information to access future performance outcomes.

Although most of the interactive coefficients are negative, as expected, they are not significant, with the exception of information on extreme top and bottom observations (dbig) and the control for IFRS adoption (ifrs). First, extreme observations reduce earnings persistence, since higher and lower-than-average earnings tend not to be as persistent as average earnings, suggesting a high portion of transitory elements in extreme observations. In other words, extreme changes of earnings tend to revert faster than low levels. This is consistent with the idea that large earnings or cash flow innovations are transitory in nature by containing non-recurrent elements (Easton \& Zmijewski, 1989).

Second, IFRS adoption in 2010 seems to reduce earnings persistence. This evidence can be supported by the idea that, by including market measures in earnings (and transitory components), IFRS has reduced the persistence of accounting earnings (Kusano, 2012).

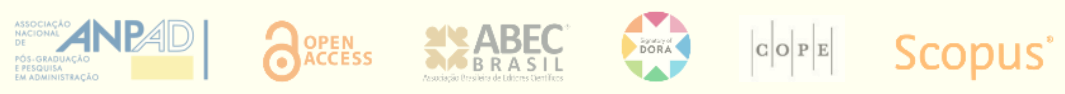


Table 3

Earnings and operating cash flow persistence parameter

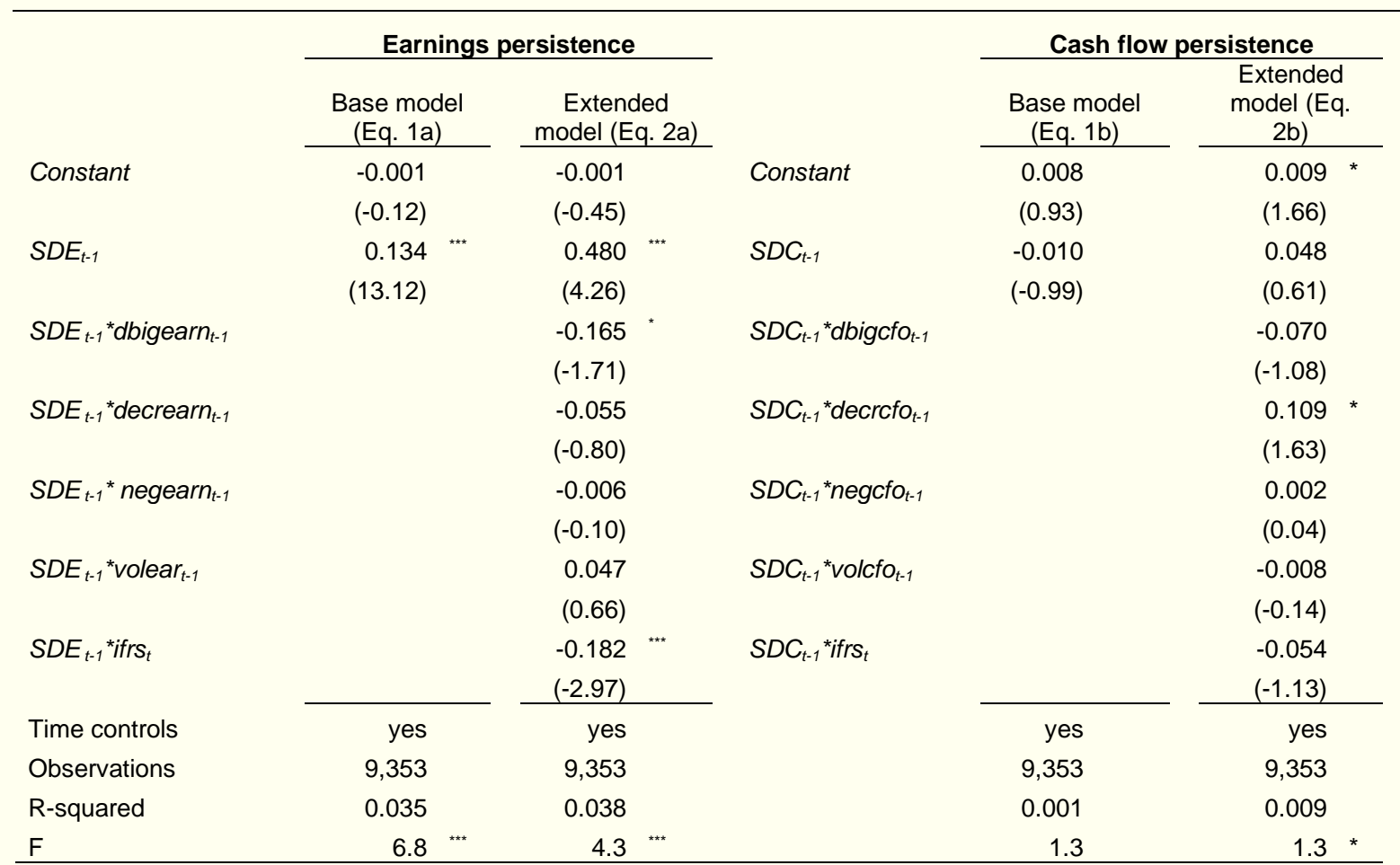

Note. Persistence parameters of earnings and operating cash flow. SDE and SDC are the seasoned difference of earnings and operating cash flow, respectively. Earnings and operating cash flow seasoned differencing variables are scaled by total assets. dbigear and dbigcfo are dummy variables assuming 1 when the change in quarter-on-quarter earnings (and operating cash flow) falls into the top or into the bottom 10 percent of the distribution and 0 otherwise. decrearn and decrcfo are dummy variables assuming 1 when earnings and operating cash decrease in relation to $t-1$ and 0 otherwise. dnegearn and dnegcfo are dummy variables for negative earnings and negative operating cash flow, respectively, assuming 1 when earnings and cash flow in $t-1$ are negative and 0 otherwise. volearn and volcfo are the rank-order of earnings and operating cash flow, respectively. ifrs is a dummy variable assuming 1 after IFRS adoption and 0 otherwise. T-statistics are in parenthesis.

${ }^{* * *},{ }^{* *}$, and ${ }^{*}$ indicate correlations statistically significant at $1 \%, 5 \%$, and $10 \%$ levels, respectively.

As the results strongly support, it is possible to conclude that quarterly earnings are more persistent than quarterly operating cash flows as suggested by the first hypothesis of this paper. The conclusion holds true for systematic and firm-specific persistence parameters and for controlled persistence estimation. These results provide evidence that under the accruals regime, the variations in cash - inflow and outflows - can be allocated or deferred throughout the economic life of assets and obligations; consequently, accruals are expected to smooth the volatile elements of cash in financial states, thus making earnings more persistent compared to cash. This evidence provides useful evidence that accounting information, based on the accruals regime, increases the predictive ability, as claimed by the current conceptual framework of IFRS, as part of the relevance of accounting information. The second hypothesis is related to the association between the magnitude of accruals and the persistence of earnings and operating cash flows. Similar to the results documented in Dechow and Ge (2006), Table 4 shows that persistence of earnings is determined by the absolute level (magnitude) of accruals in the sense that accruals improve the persistence of earnings relative to cash flows in high accrual firms, but reduce earnings persistence in low accrual firms. The controlled earnings persistence parameter for the

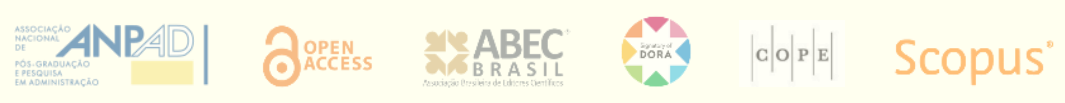


high accrual firms is 0.769 against 0.447 for the low accrual observations, being both statistically significant. Operating cash flows persistence is not statistically significant and is normally lower (negative) for high accrual observations. The remaining controlling variables show similar patterns to the entire sample.

Table 4

Earnings and operating cash flow persistence and the magnitude of accruals

\begin{tabular}{|c|c|c|c|c|c|}
\hline & \multicolumn{2}{|c|}{$\begin{array}{l}\text { Earnings persistence extended } \\
\text { model (Eq. 2a) }\end{array}$} & & \multicolumn{2}{|c|}{$\begin{array}{c}\text { Cash flow persistence extended } \\
\text { model (Eq. 2a) }\end{array}$} \\
\hline & $\begin{array}{l}\text { High accruals } \\
\text { (top 25\%) }\end{array}$ & $\begin{array}{l}\text { Low accruals } \\
\text { (bottom } 25 \% \text { ) }\end{array}$ & & $\begin{array}{l}\text { High accruals } \\
\text { (top 25\%) }\end{array}$ & $\begin{array}{l}\text { Low accruals } \\
\text { (bottom } 25 \% \text { ) }\end{array}$ \\
\hline \multirow[t]{2}{*}{ Constant } & -0.001 & -0.001 & Constant & 0.006 & -0.001 \\
\hline & $(-0.23)$ & $(-0.72)$ & & (1.59) & $(-0.81)$ \\
\hline \multirow[t]{2}{*}{$S D E_{t-1}$} & $0.769^{* *}$ & $0.447^{* * *}$ & $S D C_{t-1}$ & -0.144 & 0.070 \\
\hline & $(2.08)$ & $(2.73)$ & & $(-0.58)$ & $(0.62)$ \\
\hline \multirow[t]{2}{*}{$S D E_{t-1}^{*}{ }^{*} d b i g e a r n_{t-1}$} & -0.310 & -0.138 & $S D C_{t-1}{ }^{*} d b i g c f o r t-1$ & 0.027 & -0.024 \\
\hline & $(-0.90)$ & $(-1.10)$ & & $(0.12)$ & $(-0.27)$ \\
\hline \multirow[t]{2}{*}{$S D E_{t-1}{ }^{*}$ decrearn $n_{t-1}$} & 0.000 & $-0.197 *$ & $S D C_{t-1}{ }^{*} d_{e c r c f o} o_{t-1}$ & 0.220 & -0.114 \\
\hline & $(0.00)$ & $(-2.12)$ & & $(1.81)$ & $(-1.12)$ \\
\hline \multirow[t]{2}{*}{$S D E_{t-1}{ }^{*}$ negearn ${ }_{t-1}$} & 0.036 & 0.031 & $S D C_{t-1}^{*} n e g c f o_{t-1}$ & 0.085 & -0.071 \\
\hline & $(0.34)$ & $(0.45)$ & & $(0.89)$ & $(-0.82)$ \\
\hline \multirow[t]{2}{*}{$S D E_{t-1}^{*}$ volear $_{t-1}$} & 0.009 & 0.031 & $S D C_{t-1}^{*}$ volcfo $_{t-1}$ & -0.027 & -0.119 \\
\hline & $(0.10)$ & $(0.20)$ & & $(-0.44)$ & $(-0.54)$ \\
\hline \multirow[t]{2}{*}{$S D E_{t-1}^{*}{ }^{*} i r s_{t}$} & $-0.350^{* * *}$ & -0.159 & $S D C_{t-1}{ }^{*} i f r s_{t}$ & -0.140 & 0.079 \\
\hline & $(-2.50)$ & $(-1.63)$ & & $(-1.16)$ & $(1.19)$ \\
\hline Quarter controls & Yes & yes & & yes & yes \\
\hline Observations & 2,270 & 2,373 & & 2,270 & 2,373 \\
\hline R-squared & 0.024 & 0.038 & & 0.017 & 0.014 \\
\hline $\mathrm{F}$ & $3.3^{* \star *}$ & $3.4^{* * *}$ & & $2.1^{* *}$ & 1.8 \\
\hline
\end{tabular}

Note. Persistence parameters of earnings and operating cash flow for high and low absolute accruals. SDE and SDC are the seasoned difference of earnings and operating cash flow, respectively. Earnings and operating cash flow seasoned differencing variables are scaled by total assets. dbigear and dbigcfo are dummy variables assuming 1 when the change in quarter-on-quarter earnings (and operating cash flow) falls into the top or into the bottom 10 percent of the distribution and 0 otherwise. decrearn and decrcfo are dummy variables assuming 1 when earnings and operating cash decrease in relation to $t-1$ and 0 otherwise. dnegearn and dnegcfo are dummy variables for negative earnings and negative operating cash flow, respectively, assuming 1 when earnings and cash flow in $t-1$ are negative and 0 otherwise. volearn and volcfo are the rank-order of earnings and operating cash flow, respectively. ifrs is a dummy variable assuming 1 after IFRS adoption and 0 otherwise. T-statistics are in parenthesis. ${ }^{* * *},{ }^{* *}$, and ${ }^{*}$ indicate correlations statistically significant at $1 \%, 5 \%$, and $10 \%$ levels, respectively.

The results suggest that the magnitude of accruals significantly affects the persistence of earnings. However, no significant difference was found in the estimation of operating cash flows persistence, which confirms the second hypothesis of this paper for the effect of extreme accruals in earnings process. Hence, accruals improve the persistence of earnings relative to cash flows in high accrual firms, but reduce earnings persistence in low accrual firms (Dechow \& Ge, 2006).

While Table 4 presents the results by splitting the sample in the top and bottom absolute accrual magnitudes - allowing the direct comparison of the impact of the extreme magnitudes of accruals in the persistence parameters -, it restricts the analysis to the top and bottom accruals observations. In this regard, additionally analysis was conducted through the interaction between 
the SDE persistence parameter and the current absolute magnitude of accruals of all observation. The analysis (not reported) confirms the relation between absolute accruals and the persistence coefficient at standard significance levels when all observations are taken into consideration.

\section{Accruals and operating cash flows as components of earnings}

The previous section shows that earnings are highly and strongly persistent compared to operating cash flows. This superior ability of earnings to assess future financial outcomes is relevant to financial analysis and valuation, since it indicates that earnings are more highly predictive when compared to operating cash flows. In this regard, following Lewellen and Resutek (2019), the next step is to analyze the role of accruals and operating cash as determinants of earnings persistence.

Table 5 shows the estimates of Equations 3 (Panel A) and 4 (Panel B). The results displayed in Panel A show that both operating cash flow and accruals are positively associated with future earnings in one to three periods ahead. In all three future quarters, operating cash flow has a higher nominal coefficient than accruals suggesting that accruals are less persistent than cash flow. The evidence shows that, as components of reported quarterly earnings, accruals have lower persistence than operating cash flows, which is consistent with previous empirical literature, since accruals revert in the short term (Dechow \& Ge, 2006; Sloan, 1996; Takamatsu \& Fávero, 2013).

Additionally, as expected, results show that earnings persistence decreases over time as evidenced in Frankel and Litov (2009). Since quarterly data have, by their nature, lower persistence coefficient magnitude when compared to annual data and the time series is based on seasonally differenced earnings, results in the fourth quarter ahead show negative coefficients for operating cash flow and accruals. For annual earnings, this evidence is consistent with previous literature, which documents that "the autocorrelations at higher orders are predominantly negative" (Lipe \& Kormedi, 1994, p. 32) and that "although small individually, [the negative autocorrelations] are significant when considered in the aggregate" (Baginski et al., 1999, p. 109). Much of the prior literature that provides measures for earnings persistence restricts the analysis to such lowerorder models, without assessing the sensitivity of results to alternative ARIMA specifications. The implicit idea for the quarter approach is that in some cases, when operational activity falls in one quarter (or during a year), managers act in the direction of re-balance firms accounting in the sense of compensating past losses with future profits and this change affects both operating cash flows and accruals components.

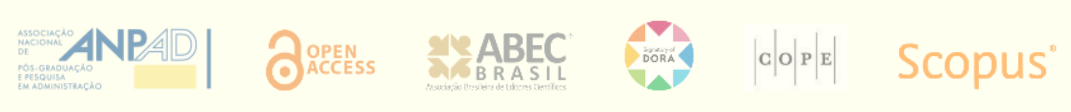


Table 5

Accruals and operating cash flows as determinant of future profitability

\begin{tabular}{|c|c|c|c|c|c|c|c|c|}
\hline \multicolumn{9}{|c|}{ Panel A - Relationship between future earnings with current accruals and cash flows (Eq. 3) } \\
\hline & \multicolumn{2}{|l|}{$t+1$} & \multicolumn{2}{|l|}{$t+2$} & \multicolumn{2}{|l|}{$t+3$} & \multicolumn{2}{|l|}{$t+4$} \\
\hline \multirow[t]{2}{*}{ Constant $\left(\gamma_{0}\right)$} & 0.001 & & 0.001 & & 0.001 & & 0.001 & $* *$ \\
\hline & $(1.55)$ & & $(1.44)$ & & $(1.45)$ & & $(2.61)$ & \\
\hline \multirow[t]{2}{*}{$\operatorname{SDC}\left(\gamma_{1}\right)$} & 0.119 & $* *$ & 0.097 & $* * *$ & 0.042 & $\star \star \star *$ & -0.283 & $* *$ \\
\hline & $(9.73)$ & & $(7.83)$ & & (3.35) & & $(-23.11)$ & \\
\hline \multirow[t]{2}{*}{$\operatorname{SDA}\left(\gamma_{2}\right)$} & 0.084 & $\star * *$ & 0.051 & $* *$ & 0.040 & $\star \star *$ & -0.272 & $* * *$ \\
\hline & $(10.02)$ & & $(6.07)$ & & $(4.60)$ & & $(-32.13)$ & \\
\hline Observations & 9,353 & & 9,079 & & 8,820 & & 8,584 & \\
\hline R-squared & 0.012 & & 0.007 & & 0.002 & & 0.108 & \\
\hline $\mathrm{F}$ & 58.1 & $* * *$ & 31.19 & $* * *$ & 10.63 & $* * *$ & 516.69 & $* * *$ \\
\hline \multicolumn{9}{|c|}{ Panel B - Relationship between future earnings with current accruals and earnings (Eq. 4) } \\
\hline & $t+1$ & & $t+2$ & & $t+3$ & & $t+4$ & \\
\hline \multirow[t]{2}{*}{ Constant $\left(\gamma_{0}^{*}\right)$} & 0.001 & * & 0.001 & & 0.001 & & 0.001 & "* \\
\hline & $(1.68)$ & & $(1.56)$ & & $(1.52)$ & & $(2.28)$ & \\
\hline \multirow[t]{2}{*}{$\operatorname{SDE}\left(\gamma_{1}^{*}\right)$} & 0.159 & $* *$ & 0.095 & $* *$ & 0.019 & & -0.337 & $* *$ \\
\hline & $(12.70)$ & & $(7.45)$ & & (1.51) & & $(-27.09)$ & \\
\hline \multirow[t]{2}{*}{$\operatorname{SDA}\left(\gamma_{2}^{*}\right)$} & -0.024 & $* * *$ & -0.025 & $* * *$ & 0.014 & * & -0.027 & $* *$ \\
\hline & $(-3.29)$ & & $(-3.35)$ & & $(1.79)$ & & $(-3.79)$ & \\
\hline Observations & 9,353 & & 9,079 & & 8,820 & & 8,584 & \\
\hline R-squared & 0.019 & & 0.006 & & 0.001 & & 0.127 & \\
\hline $\mathrm{F}$ & 91.53 & $* * *$ & 28.28 & $*$ & 6.15 & $*$ & 622.12 & $* *$ \\
\hline
\end{tabular}

Note. Dependent variable is SDE $t+T$ where $t$ varies from one to four quarters ahead. SDE, SDC, and SDA are the seasoned difference of earnings, operating cash flow, and accruals, respectively. Earnings, operating cash flow, and accruals seasoned differencing variables are scaled by total assets. T-statistics are in parentheses.

${ }^{* * *},{ }^{* *}$, and ${ }^{*}$ indicate correlations statistically significant at $1 \%, 5 \%$, and $10 \%$ levels, respectively.

Panel B of Table 5 shows that, controlling for current earnings, the low persistence of accruals, $\gamma_{2}^{*}<0$, indicates that accruals are negatively related to future earnings (Lewellen $\&$ Resutek, 2019). This conclusion holds statistically significant for one to four quarters ahead with the exception of the third quarter, in which results show a positive and significant coefficient. This evidence suggests that, even controlling for quarter seasonality by seasonal differencing the financial variables, accruals and cash are subject to changes among quarters. Hence, the evidence reinforces the importance of quarterly analysis, since these differences are not captured in annual earnings.

Overall, results in Table 5 suggest the acceptance of hypotheses 3 and 4 of this paper, that is, operating cash flows are more persistent than accruals as a component of earnings $\left(\gamma_{1}>\gamma_{2}\right)$ and accruals levels are negatively associated with future (subsequent) earnings $\left(\gamma_{2}^{*}<0\right)$. 


\section{The predictive power of future earnings and operating cash flow}

In order to analyze the association between future cash flows with current and lagged values and the incremental information of earnings and accruals, future operating cash flows were regressed with their lagged values and the lagged values of accruals (according to Equation 5). Additionally, analysis of variance decomposition of a linear regression of future values of cash flows with contemporaneous values of these variables (Equation 6) was conducted.

Results displayed in Panel A of Table 6 show positive and significant coefficients of accruals component $\left(\delta_{3}\right.$ and $\left.\delta_{4}\right)$ suggesting that accruals have incremental information content over cash flow alone (Farshadfar \& Monem, 2019). The significant relationships hold true for both quarterto-quarter (adjacent) and quarter-by-quarter (seasonal) coefficients in one to four quarters ahead.

Additionally, Table 6 - Panel B shows the percentage of the variance of future values of cash flows explained by their current values (in the adjacent and seasonal approaches). Firstly, the seasonal approach (four quarters ahead, $t+4$ ) explains less than adjacent analysis (one quarter ahead, $t+1$ ) for cash flow estimation (3.5\% against $4.4 \%$, in Panel B).

Secondly, current earnings explain more about future cash flow in the seasonal approach (in Panel B, 2.3\% against 1.4\%).

Finally, in all cases - operating cash flows in adjacent and seasonal analyses - high accruals firms explain more about future cash flows than the overall sample and low accrual firms. This evidence strongly supports the hypothesis that accruals have additional and complementary informative power to forecast future operating cash flows, corroborating the fifth hypothesis of this paper.

Table 6

The relevance of quarterly accruals in estimate future operating cash flows

\begin{tabular}{|c|c|c|c|c|c|c|c|c|}
\hline \multicolumn{9}{|c|}{ Panel A - Direct effect of accruals on adjacent and seasonal accruals } \\
\hline \multirow{3}{*}{ Constant $\left(\delta_{0}\right)$} & \multicolumn{2}{|c|}{$t+1$} & \multicolumn{2}{|c|}{$t+2$} & \multicolumn{2}{|c|}{$t+3$} & \multicolumn{2}{|l|}{$t+4$} \\
\hline & 0.006 & 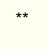 & 0.007 & ** & 0.003 & & 0.003 & \\
\hline & $(2.30)$ & & $(2.46)$ & & $(1.48)$ & & $(1.16)$ & \\
\hline \multirow[t]{2}{*}{$c f O_{t}\left(\delta_{1}\right)$} & 0.225 & $* * *$ & 0.137 & $* * *$ & 0.013 & $* \star \star$ & 0.202 & $* * *$ \\
\hline & $(19.20)$ & & $(10.94)$ & & $(19.38)$ & & $(14.50)$ & \\
\hline \multirow{2}{*}{$c f \mathrm{O}_{t-3}\left(\delta_{2}\right)$} & 0.182 & $* * *$ & 0.111 & $* *$ & 0.015 & $* * *$ & 0.293 & $* * *$ \\
\hline & (13.68) & & (7.89) & & $(9.41)$ & & (19.11) & \\
\hline \multirow[t]{2}{*}{$\operatorname{accr}_{t}\left(\delta_{3}\right)$} & 0.061 & $* * *$ & 0.094 & $* * *$ & 0.015 & $* * *$ & 0.141 & $* * *$ \\
\hline & $(4.64)$ & & (6.36) & & $(7.74)$ & & $(8.43)$ & \\
\hline \multirow[t]{2}{*}{$\operatorname{accr}_{t-1}\left(\delta_{4}\right)$} & 0.122 & $* * *$ & 0.059 & $* * *$ & 0.018 & $* * *$ & 0.025 & \\
\hline & $(7.71)$ & & $(3.46)$ & & $(-3.54)$ & & $(1.26)$ & \\
\hline Observations & 9,648 & & 9,374 & & 9,106 & & 8,839 & \\
\hline R-squared & 0.0746 & & 0.0253 & & 0.0779 & & 0.0829 & \\
\hline $\mathrm{F}$ & 195.390 & $* * *$ & 60.89 & $* * *$ & 192.14 & $* * *$ & 200.79 & $* * *$ \\
\hline
\end{tabular}

Continues

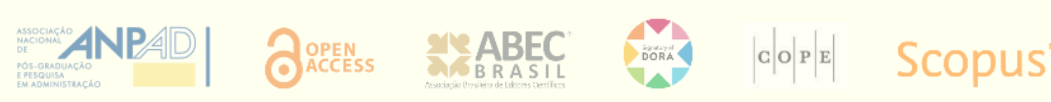




\section{Table 6 (continued)}

Panel B - Variance decomposition of future operating cash flow (in \%)

One quarter ahead (quarter-by-quarter)

\begin{tabular}{|c|c|c|c|c|c|c|c|}
\hline & $\begin{array}{r}\text { All } \\
\text { observ. }\end{array}$ & $\begin{array}{r}\text { High } \\
\text { accruals }\end{array}$ & $\begin{array}{r}\text { Low } \\
\text { accruals }\end{array}$ & & $\begin{array}{r}\text { All } \\
\text { observ. }\end{array}$ & $\begin{array}{r}\text { High } \\
\text { accruals }\end{array}$ & Low accruals \\
\hline earn (\%) & 1.4 & 2.3 & 1.3 & earn (\%) & 2.3 & 4.8 & 2.2 \\
\hline cfo (\%) & $\underline{3.0}$ & $\underline{4.0}$ & $\underline{3.0}$ & cfo (\%) & $\underline{1.3}$ & $\underline{2.4}$ & $\underline{1.3}$ \\
\hline Total lagged (\%) & 4.4 & 6.2 & 4.3 & Total lagged (\%) & 3.5 & 7.2 & 3.5 \\
\hline
\end{tabular}

Note. Regression-based inequality variance following Fields (2003). Figures show the percentage of forward earnings and cash flows variance explained by prior values of earnings and cash flows from operation.

${ }^{* * *},{ }^{* *}$, and ${ }^{*}$ indicate correlations statistically significant at $1 \%, 5 \%$, and $10 \%$ levels, respectively.

Evidently, the percentages displayed in Table 6 do not answer all the questions about earnings and cash flow variance. Many additional macroeconomic and firm-specific factors strongly influence the variance of the variables; thus, the objective of the analysis is to show the incremental ability of cash and accruals in estimating future values of earnings and operating cash flows. In this sense, overall results support the relevance of accruals to estimate future financial outputs, especially in long-term (seasonal) analysis.

\section{ADDITIONAL TESTS, ALTERNATIVE ASSUMPTIONS, AND EXTENSIONS}

As mentioned in previous sections, the earnings and cash flow persistence was based on the wellaccepted quarterly time series model in the literature (the seasonal differenced earnings approach), which provides effective empirical results (Baginski et al., 2003; Brown \& Rozeff, 1979; Chen, 2013; Easton \& Zmijewski, 1989; Foster, 1977; Kormendi \& Lipe, 1987; Lorek \& Willinger, 1996) and motivates the presentations of the results above. However, at the same time, the literature is not unanimous in defining a time series model that represents earnings and cash flow in all conditions and environments (Kothari, 2001; Lorek \& Willinger, 2009). The conflicting literature combined with low significance and low explanatory power of operating cash flow displayed in this paper motivates the performance of alternative models that consider earnings and cash flows as first-order autoregressive quarter-to-quarter (adjacent) and quarter-byquarter (seasonal) relationships for all the equations (Lorek \& Willinger, 1996; Lorek \& Willinger, 2009).

Table 7 shows the results for the base (Panel A) and extended models (Panel B) in non-integrated autoregressive models. As expected, non-integrated models increase in magnitude of persistence coefficients for both cash and earnings into either of the models, adjacent $(t-1)$ or seasonal $(t-4)$. In Panel $\mathrm{A}$, results show that the autoregressive parameters of quarterly earnings are higher in both adjacent and seasonal approaches, reinforcing the acceptance of the first hypothesis in this paper (i.e., earnings are more persistent than cash). In the extended model (controlled model) presented in Panel B, the earnings autoregressive coefficient is significantly higher than operating cash flow in adjacent ( $t-1)$ analysis, suggesting higher persistence of earnings as stated in the first
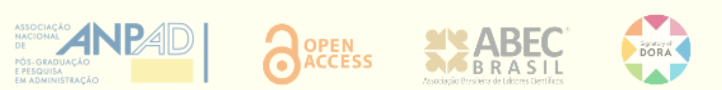
hypothesis of this paper. However, the coefficients are indistinguishable at the seasonal analysis $(t-4)$. The improved results for operating cash flows suggest that cash flow can be better described as a first-order autoregressive seasonal model. However, even in the improved modeling, it is not possible to say that cash flows are more persistent than earnings.

Table 7

Base and extended models of earnings and operating cash flow autoregressive adjacent $(t-1)$ and seasonal $(t-4)$ persistence parameters

Panel A - Base model autoregressive parameters

Adjacent ( $t-1)$

\begin{tabular}{|c|c|c|}
\hline & $\begin{array}{c}\text { Earnings } \\
\text { (earn) }\end{array}$ & $\begin{array}{l}\text { Op. cash flow } \\
(c f o)\end{array}$ \\
\hline \multirow[t]{2}{*}{ Constant } & -0.011 & 0.001 \\
\hline & $(-2.35)$ & $(0.24)$ \\
\hline \multirow[t]{2}{*}{ AR parameter } & $0.285^{* * *}$ & 0.200 \\
\hline & $(30.36)$ & $(20.85)$ \\
\hline Period controls & yes & yes \\
\hline Obs. & 10,483 & 10,483 \\
\hline R-squared & 0.081 & 0.040 \\
\hline $\mathrm{F}$ & 231.3 & 109.4 \\
\hline
\end{tabular}

Seasonal $(t-4)$

\begin{tabular}{|c|c|}
\hline $\begin{array}{c}\text { Earnings } \\
\text { (earn) }\end{array}$ & $\begin{array}{l}\text { Op. cash flow } \\
\text { (cfo) }\end{array}$ \\
\hline$-0.011^{* *}$ & 0.002 \\
\hline$(-2.33)$ & $(0.31)$ \\
\hline $0.340^{* * *}$ & $0.166^{* \star *}$ \\
\hline (29.90) & $(15.71)$ \\
\hline yes & yes \\
\hline 9,675 & 9,675 \\
\hline 0.085 & 0.025 \\
\hline 224.2 & 62.1 \\
\hline
\end{tabular}

Panel B - Extended model autoregressive parameters

\begin{tabular}{|c|c|c|c|c|c|c|c|}
\hline \multicolumn{4}{|c|}{ Adjacent (t-1) } & \multicolumn{4}{|c|}{ Seasonal $(t-4)$} \\
\hline & $\begin{array}{l}\text { Earnings } \\
\text { (earn) }\end{array}$ & & $\begin{array}{c}\text { Cash flow } \\
\text { (cfo) }\end{array}$ & & $\begin{array}{c}\text { Earnings } \\
\text { (earn) }\end{array}$ & & $\begin{array}{c}\text { Cash flow } \\
\text { (cfo) }\end{array}$ \\
\hline \multirow[t]{2}{*}{ Const. } & -0.002 & Const. & $0.010^{*}$ & Const. & -0.002 & Const. & $0.003^{* * *}$ \\
\hline & $(-0.43)$ & & $(1.75)$ & & $(-0.35)$ & & $(0.47)$ \\
\hline \multirow[t]{2}{*}{$e^{e a r n} n_{t-1}$} & $0.646^{* * *}$ & $c f O_{t-1}$ & $0.487^{* * *}$ & $\operatorname{earn}_{t-4}$ & $0.631^{* * *}$ & $c f O_{t-4}$ & $0.690^{* * *}$ \\
\hline & (3.72) & & $(3.40)$ & & (3.38) & & (4.35) \\
\hline \multirow[t]{2}{*}{ eart $_{t-1}^{*}$ dbigearn $n_{t-1}$} & $-0.680^{* * *}$ & $\begin{array}{l}c f o_{t-1}{ }^{*} \\
d b i g c f o_{t-1}\end{array}$ & $-0.520^{\cdots *}$ & $\begin{array}{l}\text { ear }_{t-4}^{*} \\
\text { dbigearn }_{t-4}\end{array}$ & $-0.663^{* *}$ & $\begin{array}{l}c^{c o_{t-4}}{ }^{*} \\
\text { dbigcfo }_{t-4}\end{array}$ & $-0.667^{* * *}$ \\
\hline & $(-3.92)$ & & $(-3.64)$ & & $(-3.55)$ & & $(-4.21)$ \\
\hline \multirow[t]{2}{*}{ eart-1 $_{t}^{*}$ decrearn $n_{t-1}$} & 0.086 & $\begin{array}{l}\operatorname{cfo}_{t-1}{ }^{*} \\
\text { decrcfot }_{t-1}\end{array}$ & $-0.348^{* * *}$ & $\begin{array}{l}\text { eart }^{*}{ }^{*} \\
\text { decrearn }\end{array}$ & -0.344 & $\begin{array}{l}\operatorname{cfo}_{t-4}{ }^{\star} \\
\text { decrcfo }_{t-4}\end{array}$ & $-0.300^{* * *}$ \\
\hline & $(1.55)$ & & $(-3.23)$ & & $(-5.99)$ & & $(-2.54)$ \\
\hline \multirow[t]{2}{*}{ eart-1 $_{t}^{*}$ negearn $t_{t-1}$} & $0.417^{* * *}$ & $\begin{array}{l}\text { cfo }_{t-1}{ }^{*} \\
\text { negcfot }\end{array}$ & $0.703^{* * *}$ & $\begin{array}{l}\text { ear }_{t-4}^{*} \\
\text { negearn }_{t-4}\end{array}$ & $1.062^{* * *}$ & $\begin{array}{l}\text { cfo }_{t-4}{ }^{*} \\
\text { negcfo }_{t-4}\end{array}$ & $0.510^{* * *}$ \\
\hline & $(7.37)$ & & $(6.44)$ & & $(18.28)$ & & $(4.27)$ \\
\hline Period controls & yes & & yes & & yes & & yes \\
\hline Obs & 9,384 & & 9,384 & & 8,584 & & 8,584 \\
\hline R-squared & 0.146 & & 0.079 & & 0.187 & & 0.036 \\
\hline $\mathrm{F}$ & $228.34^{* * *}$ & & $115.2^{* * *}$ & & $281.74^{* * *}$ & & $45.72^{* * *}$ \\
\hline
\end{tabular}

Note. Autoregressive parameters for one and four lags structure of earnings, operating cash flow, and accruals. Financial variables are scaled by total assets. dbigear and dbigcfo are dummy variables assuming 1 when the change in quarter-on-quarter earnings (and operating cash flow) falls into the top or into the bottom 10 percent of the distribution and 0 otherwise. decrearn and decrcfo are dummy variables assuming 1 when earnings and operating cash decrease in relation to $t-1$ and 0 otherwise. dnegearn and dnegcfo are dummy variables for negative earnings and negative operating cash flow, respectively, assuming 1 when earnings and cash flow in $t-1$ are negative and 0 otherwise. T-statistics are in parentheses.

${ }_{* * *},{ }^{* *}$, and ${ }^{*}$ indicate correlations statistically significant at $1 \%, 5 \%$, and $10 \%$ levels, respectively. 
The remaining regressions were also conducted under non-integrated autoregressive models and the results are qualitatively the same (with relevant increases in models' magnitudes and significances, however): Firstly, high accruals are associated with higher magnitude of earnings persistence. Secondly, accruals are less persistent than operating cash flows (Equation 3). Thirdly, accruals are negatively associated with future returns (Equation 4). These results, not presented in this paper due to space restrictions, confirm the findings under non-integrated autoregressive models for adjacent and seasonal analysis and are available upon request.

\section{CONCLUSION}

This paper analyzes the role of quarterly data of earnings, cash flow from operation, and accruals, and their assessment of future performance. Specifically, the paper (1) compares the time persistence of earnings and operating cash flows, (2) analyzes the role of cash flows and accruals as components of earnings, and (3) analyzes the role of accruals informativeness to explain future cash flows. The empirical analysis is based on 270 Brazilian non-financial firms listed on B3 from 2005 to 2018 (10,792 firm-quarter observations). Autoregressive models and variance decomposition of future financial performance measures were performed in the empirical test estimations.

Overall, results show that accounting earnings and accruals contained in earnings have incremental information content over operating cash flows in assessing future financial performance: First, earnings have higher persistence parameters and capture a longer-term perspective of time series components than cash flows from operations. Hence, earnings, under the accrual accounting regime, are more predictable than cash flows by using their past information. The results also document that the magnitude of accruals is positively associated with the persistence of earnings, suggesting that high levels of nominal accruals increase performance persistence.

Results also document that operating cash flows are more persistent than accruals as components of earnings, suggesting that accruals are more reversible along time. Additionally, high accrual levels are associated with lower future earnings. Finally, results show that earnings and accruals have incremental informative power to explain future operating cash flows.

Due to low effectiveness of analysts and investors to provide accurate forecasts and to the lack of fully recognition of the time series process of quarterly earnings and cash flows documented in previous literature (Bradshaw et al., 2012; Chen, 2013), the results presented in this paper suggest that market agents would benefit from conducting a careful examination of quarterly operating cash flows and accruals when interpreting current quarterly earnings. The practical implication of understanding the earnings and operating cash flows process is increased in emerging markets such as the Brazilian market, which has low levels of analyst coverage, investor protection, and restriction enforcement mechanisms.

Hence, portfolio managers, investors, and market analysts may take more informed decisions and accurate forecasts by incorporating quarterly accruals and operating cash flows in their analyses.
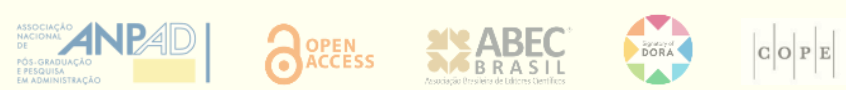
Moreover, taking into consideration that different accruals processes related to extreme, reducing, negative, and volatile financial performance reduce earnings and cash flows persistence parameters, the modeling of the financial performance forecast can be enhanced. This means that more persistent earnings and operating cash flows are better inputs to valuation models and that the high or low persistence and predictability is related to the pattern of earnings, operating cash flows, and, specially, accruals: financial performances with different accruals processes and anomalies have different predictability power.

This paper follows, and is restricted to, a well-established research venue in developed markets analyzing the time series process of earnings and the relevance of accruals to future financial performance. A natural extension to this study is to analyze the market reaction to these earnings processes and evaluate if market agents are able to incorporate such characteristics to market prices and security valuation. An additional approach is to compare different countries and the differences of the earnings process according to macroeconomic events and environment.

\section{REFERENCES}

Baginski, S. P., Branson, B. C., Lorek, K. S., \& Willinger, G. L. (2003). A time-series approach to measuring the decline in quarterly earnings persistence. Advances in Accounting, 20, 23-42. https://doi.org/10.1016/S08826110(03)20002-X

Baginski, S. P., Lorek, K. S., Willinger, G. L., \& Branson, B. C. (1999). The relationship between economic characteristics and alternative annual earnings persistence measures. The Accounting Review, 74(1), 105-120. https://doi.org/10.2308/accr.1999.74.1.105

Ball, R., Gerakos, J., Linnainmaa, J. T., \& Nikolaev, V. (2016). Accruals, cash flows, and operating profitability in the cross section of stock returns. Journal of Financial Economics, 121(1), 28-45. https://doi.org/10.1016/j.jfineco.2016.03.002

Barth, M. E., Clinch, G., \& Israeli, D. (2016). What do accruals tell us about future cash flows? Review of Accounting Studies, 21(3), 768-807. https://doi.org/10.1007/s11142-016-9360-4

Barth, M. E., Landsman, W. R., \& Lang, M. H. (2008). International accounting standards and accounting quality. Journal of Accounting Research, 46(3), 467-498. https://doi.org/10.1111/j.1475-679X.2008.00287.x

Barth, M. E., Cram, D. P., \& Nelson, K. K. (2001). Accruals and the Prediction of Future Cash Flows. The Accounting Review, 76(1), 27-58. https://doi.org/10.2308/accr.2001.76.1.27

Bartov, E., Goldberg, S. R., \& Kim, M.-S. (2001). The Valuation-relevance of Earnings and Cash Flows: an International Perspective. Journal of International Financial Management EF Accounting, 12(2), 103-132. https://doi.org/10.1111/1467-646X.00068

Bradshaw, M. T., Drake, M. S., Myers, J. N., \& Myers, L. A. (2012). A re-examination of analysts' superiority over time-series forecasts of annual earnings. Review of Accounting Studies, 17(4), 944-968. https://doi.org/10.1007/s11142-012-9185-8

Brown, L. D., \& Rozeff, M. S. (1979). Univariate time-series models of quarterly accounting earnings per share: A proposed model. Journal of Accounting Research, 17(1), 179-189. https://doi.org/10.2307/2490312

Byard, D., Li, Y., \& Yu, Y. (2011). The effect of mandatory IFRS adoption on financial analysts' information environment. Journal of Accounting Research, 49(1), 69-96. https://doi.org/10.1111/j.1475-679X.2010.00390.x

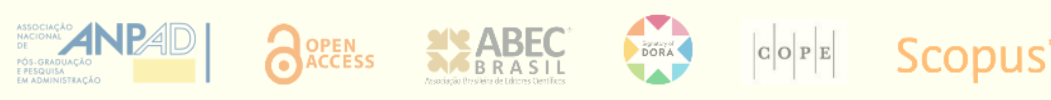


Call, A. C., Hewitt, M., Shevlin, T., \& Yohn, T. L. (2016). Firm-specific estimates of differential persistence and their incremental usefulness for forecasting and valuation. The Accounting Review, 91(3), 811-833. https://doi.org/10.2308/accr-51233

Chen, C. (2013). Time-varying earnings persistence and the delayed stock return reaction to earnings announcements. Contemporary Accounting Research, 30(2), 549-578. https://doi.org/10.1111/j.1911. 3846.2012.01165.x

Clubb, C., \& Wu, G. (2014). Earnings volatility and earnings prediction: Analysis and UK Evidence. Journal of Business Finance $\mathcal{E}$ Accounting, 41(1-2), 53-72. https://doi.org/10.1111/jbfa.12055

Coelho, A. C., Aguiar, A. B. d., \& Lopes, A. B. (2011). Relationship between abnormal earnings persistence, industry structure, and market share in Brazilian public firms. BAR-Brazilian Administration Review, 8(1), 48-67. http://dx.doi.org/10.1590/S1807-76922011000100005

Cupertino, C. M., Martinez, A. L., \& Costa Jr., N. C. A. d. (2012). Accrual anomaly in the Brazilian capital market. BAR - Brazilian Administration Review, 9(4), 421-440. https://dx.doi.org/10.1590/S180776922012005000005

Dechow, P., Ge, W., \& Schrand, C. (2010). Understanding earnings quality: A review of the proxies, their determinants and their consequences. Journal of Accounting and Economics, 50(2-3), 344-401. http://dx.doi.org/10.1016/j.jacceco.2010.09.001

Dechow, P. M., \& Ge, W. (2006). The persistence of earnings and cash flows and the role of special items: Implications for the accrual anomaly. Review of Accounting Studies, 11(2), 253-296. https://doi.org/10.1007/s11142-006-9004-1

Easton, P. D., \& Zmijewski, M. E. (1989). Cross-sectional variation in the stock market response to accounting earnings announcements. Journal of Accounting and Economics, 11(2), 117-141. https://doi.org/10.1016/01654101(89)90003-7

Fama, E. F., \& French, K. R. (2000). Forecasting profitability and earnings. The Journal of Business, 73(2), 161-175. Retrieved from https://www.jstor.org/stable/10.1086/209638

Farshadfar, S., \& Monem, R. M. (2019). Further evidence of the relationship between accruals and future cash flows. Accounting E⿱ Finance, 59(1), 143-176. http://doi.org/10.1111/acfi.12260

Fields, G. S. (2003). Accounting for income inequality and its change: A new method, with application to the distribution of earnings in the United States (pp. 1-38). In S. W. Polachek (Ed.), Worker Well-Being and Public Policy. Bingley: Emerald Group.

Foster, G. (1977). Quarterly accounting data: Time-series properties and predictive-ability results. The Accounting Review, 52(1), 1-21. https://www.jstor.org/stable/246028

Francis, R. N., Glandon, S., \& Olsen, L. (2013). The persistence of current and proposed measures of operating cash flow. Research in Accounting Regulation, 25(2), 157-168. https://doi.org/10.1016/j.racreg.2013.08.004

Frankel, R., \& Litov, L. (2009). Earnings persistence. Journal of Accounting and Economics, 47(1), 182-190. https://doi.org/10.1016/j.jacceco.2008.11.008

Gatsios, R. C., Lima, F. G., \& Magnani, V. M. (2018). The impact of IFRS adoption on the accuracy and dispersion of analysts' forecasts in the Brazilian stock market. Economics Bulletin, 38(4), 2389-2398. Retrieved from https://ideas.repec.org/a/ebl/ecbull/eb-18-00869.html

Hou, K., Van Dijk, M. A., \& Zhang, Y. (2012). The implied cost of capital: A new approach. Journal of Accounting and Economics, 53(3), 504-526. https://doi.org/10.1016/j.jacceco.2011.12.001

Hribar, P., \& Collins, D. W. (2002). Errors in estimating accruals: Implications for empirical research. Journal of Accounting Research, 40(1), 105-134. https://doi.org/10.1111/1475-679X.00041

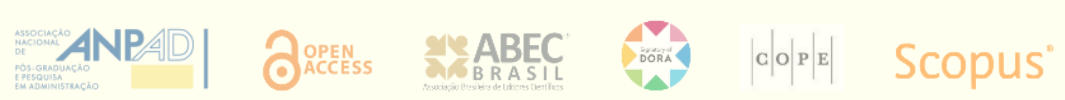


Hui, K. W., Nelson, K. K., \& Yeung, P. E. (2016). On the persistence and pricing of industry-wide and firm-specific earnings, cash flows, and accruals. Journal of Accounting and Economics, 61(1), 185-202. https://doi.org/10.1016/j.jacceco.2015.06.003

Kolozsvari, A. C., \& Macedo, M. A. d. S. (2016). Analysis of the influence of income smoothing over earnings persistence in the Brazilian market. Revista Contabilidade $\mathscr{E}$ Finanças, 27(72), 306-319. http://dx.doi.org/10.1590/1808-057x201602610

Kormendi, R., \& Lipe, R. (1987). Earnings innovations, earnings persistence, and stock returns. Journal of Business, 60(3), 323-345. http://dx.doi.org/10.1086/296400

Kothari, S. P. (2001). Capital markets research in accounting. Journal of Accounting and Economics, 31(1-3), 105-231. http://dx.doi.org/10.1016/S0165-4101(01)00030-1

Kusano, M. (2012). Does the balance sheet approach improve the usefulness of accounting information? The Japanese Accounting Review, 2(2012), 139-152. https://doi.org/10.11640/tjar.2.2012_139

Lacina, M., Lee, B. B., \& Xu, R. Z. (2011). An evaluation of financial analysts and naïve methods in forecasting longterm earnings. Advances in Business and Management Forecasting, 8, 77-101. https://doi.org/10.1108/S14774070(2011)0000008009

Larson, C. R., Sloan, R., \& Zha Giedt, J. (2018). Defining, measuring, and modeling accruals: a guide for researchers. Review of Accounting Studies, 23(3), 827-871. http://doi.org/10.1007/s11142-018-9457-z

Leal, L. T. Y., Girao, L. F. D. A. P., Lucena, W. G. L., \& Martins, V. G. (2017). Persistence, value relevance, and accruals quality in extreme earnings and cash flow situations. RAM. Revista de Administração Mackenzie, 18(3), 203-231. http://dx.doi.org/10.1590/1678-69712017

Lewellen, J., \& Resutek, R. J. (2019). Why do accruals predict earnings? Journal of Accounting and Economics, 67(2), 336-356. https://doi.org/10.1016/j.jacceco.2018.12.003

Lipe, R., \& Kormendi, R. (1994). Mean reversion in annual earnings and its implications for security valuation. Review of Quantitative Finance and Accounting, 4(1), 27-46. https://doi.org/10.1007/BF01082663

Livnat, J., \& Espinosa, G. L. (2008). Quarterly accruals or cash flows in portfolio construction? Financial Analysts Journal, 64(3), 67-79. http://doi.org/10.2469/faj.v64.n3.7

Livnat, J., \& Santicchia, M. (2006). Cash flows, accruals, and future returns. Financial Analysts Journal, 62(4), 48-61. http://doi.org/10.2469/faj.v62.n4.4186

Lorek, K. S., \& Willinger, G. L. (1996). A Multivariate time-series prediction model for cash-flow data. The Accounting Review, 71(1), 81-102. https://www.jstor.org/stable/248356

Lorek, K. S., \& Willinger, G. L. (2009). The time-series properties of quarterly cash flows. [Working Paper Series - 9-12]. Retrieved from https://pdfs.semanticscholar.org/560d/633baaffd549ea2ed6001ad9b898de8b8df0.pdf

Malacrida, M. J. C., de Lima, G. A. F., Favero, L. P. L., \& Lima, I. S. (2010). An accounting accruals model to predict future operating cash flows: evidence from Brazil. International Journal of Management, 27(3), 562-578. Retrieved from https://www.questia.com/library/journal/1P3-2184287411/an-accounting-accruals-model-to-predictfuture-operating

Nichols, D. C., \& Wahlen, J. M. (2004). How do earnings numbers relate to stock returns? A Review of classic accounting research with updated evidence. Accounting Horizons, 18(4), 263-286. http://doi.org/10.2308/acch.2004.18.4.263

Ohlson, J. A. (1995). Earnings, book values, and dividends in equity valuation. Contemporary Accounting Research, 11(2), 661-687. https://doi.org/10.1111/j.1911-3846.1995.tb00461.x

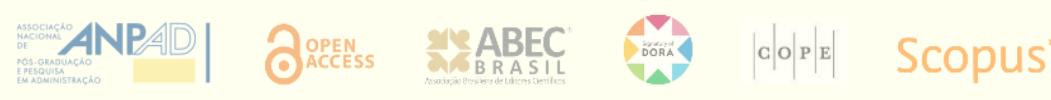


Olsen, R. A. (1996). Implications of herding behavior for earnings estimation, risk assessment, and stock returns. Financial Analysts Journal, 52(4), 37-41. https://doi.org/10.2469/faj.v52.n4.2009

Pimentel, R. C. (2015). Unexpected earnings, stock returns, and risk in the brazilian capital market. Revista Contabilidade EF Finanças, 26(69), 290-303. http://dx.doi.org/10.1590/1808-057x201501270

Pimentel, R. C., \& Aguiar, A. B. (2012). Persistence of quarterly earnings: an empirical investigation in Brazil. Brazilian Business Review, 10 (Special Ed.), 38-54. https://doi.org/10.15728/bbrconf.2012.2

Pimentel, R. C., \& Aguiar, A. B. (2016). The role of earnings persistence in valuation accuracy and the time horizon. Revista de Administração de Empresas, 56(1), 71-86. https://doi.org/10.15728/bbrconf.2012.2

Pimentel, R. C., \& Lima, I. S. (2015). Market reaction to annual earnings innovations and alternative time-series assumptions: evidence of the Brazilian market. Revista de Contabilidade e Organizações, 9(25), 56-72. http://dx.doi.org/10.11606/rco.v9i25.89534

Scott, W. R. (2015). Financial Accounting Theory Seventh Edition. Upper Saddle River, NJ: Pearson.

Sloan, R. G. (1996). Do Stock Prices Fully reflect information in accruals and cash flows about future earnings? The Accounting Review, 71(3), 289-315. https://www.jstor.org/stable/248290

Takamatsu, R. T., \& Fávero, L. P. L. (2013). Accruals, persistence of profits and stock returns in Brazilian Public Companies. Modern Economy, 4(2), 109-118. http://dx.doi.org/10.4236/me.2013.42014

\section{Authors' contributions}

$1^{\text {st }}$ author: conceptualization (equal), data curation (equal), formal analysis (lead), investigation (lead), methodology (lead), project administration (equal), resources (equal), supervision (equal), writing-original draft (supporting), writing-review \& editing (supporting).

$2^{\text {nd }}$ author: conceptualization (equal), data curation (supporting), formal analysis (supporting), project administration (equal), resources (equal), supervision (equal), validation (equal), writing-original draft (supporting), writing-review $\&$ editing (supporting)

\section{Authors}

\section{Rene Coppe Pimentel*}

Universidade de São Paulo

Av. Luciano Gualberto, 908 FEA 3, 05508-010, São Paulo, SP, Brazil

renecp@usp.br

(iD) https://orcid.org/0000-0002-8845-049X

\section{Mara Jane Contrera Malacrida}

Universidade de São Paulo

Av. Luciano Gualberto, 908 FEA 3, 05508-010, São Paulo, SP, Brazil

maracont@usp.br

(iD) https://orcid.org/0000-0002-1157-6799

* Corresponding author

Peer review is responsible for acknowledging an article's potential contribution to the frontiers of scholarly knowledge on business or public administration. The authors are the ultimate responsible for the consistency of the theoretical references, the accurate report of empirical data, the personal perspectives, and the use of copyrighted material. This content was evaluated using the double-blind peer review process. The disclosure of the reviewers' information on the first page is made only after concluding the evaluation process, and with the voluntary consent of the respective reviewers. 